\title{
Temperature effects on carbon-specific respiration rate and sinking velocity of diatom aggregates - potential implications for deep ocean export processes
}

\author{
M. H. Iversen ${ }^{1}$ and H. Ploug ${ }^{2,3}$ \\ ${ }^{1}$ Faculty of Geosciences and MARUM, University of Bremen, Klagenfurter and Leobener Strasse, 28359 Bremen, Germany \\ ${ }^{2}$ Alfred Wegener Institute for Polar and Marine Research, Am Handelshafen 12, 27570 Bremerhaven, Germany \\ ${ }^{3}$ University of Gothenburg, Dept. of Biology and Environmental Sciences, P.O. Box 461, 40530 Gothenburg, Sweden
}

Correspondence to: M. H. Iversen (morten.iversen@uni-bremen.de)

Received: 28 November 2012 - Published in Biogeosciences Discuss.: 8 January 2013

Revised: 28 March 2013 - Accepted: 17 April 2013 - Published: 20 June 2013

\begin{abstract}
Most deep ocean carbon flux profiles show low and almost constant fluxes of particulate organic carbon (POC) in the deep ocean. However, the reason for the nonchanging POC fluxes at depths is unknown. This study presents direct measurements of formation, degradation, and sinking velocity of diatom aggregates from laboratory studies performed at $15^{\circ} \mathrm{C}$ and $4{ }^{\circ} \mathrm{C}$ during a three-week experiment. The average carbon-specific respiration rate during the experiment was $0.12 \pm 0.03$ at $15^{\circ} \mathrm{C}$, and decreased 3.5fold when the temperature was lowered to $4^{\circ} \mathrm{C}$. No direct influence of temperature on aggregate sinking speed was observed. Using the remineralisation rate measured at $4{ }^{\circ} \mathrm{C}$ and an average particle sinking speed of $150 \mathrm{~m} \mathrm{~d}^{-1}$, calculated carbon fluxes were similar to those collected in deep ocean sediment traps from a global data set, indicating that temperature plays a major role for deep ocean fluxes of POC.
\end{abstract}

\section{Introduction}

Macroscopic aggregates with diameters larger than $0.5 \mathrm{~mm}$ are known as marine snow and formed from detritus, living organisms, and inorganic matter in both coastal zones and the open ocean (Alldredge and Silver, 1988). Sedimentation of marine snow and fecal pellets drives the export of organic matter from the surface to the deep ocean (Fowler and Knauer, 1986; Asper, 1987) and often occurs at sinking velocities exceeding $100 \mathrm{~m}$ day $^{-1}$ (e.g. Alldredge and Gotschalk, 1988; Diercks and Asper, 1997; Asper and Smith,
2003). This is termed "the biological pump" (Volk and Hoffert, 1985), which is characterised by continuous consumption and remineralisation of the settling aggregates, resulting in high attenuation of carbon fluxes with increasing depth in the euphotic and upper mesopelagic zone (e.g. Martin et al., 1987). The efficiency of the biological pump is mainly determined by aggregate sinking velocities and degradation rates of the organic material within settling aggregates, with high export when sinking velocities are high and/or degradation rates are low.

Remineralisation of particulate organic carbon (POC) by heterotrophic organisms in the ocean is high, and often more than $90 \%$ of the produced POC is solubilised and respired before settling through the euphotic zone (Hedges, 1992). Generally, there is strong attenuation of POC fluxes within the upper hundreds of metres in the open ocean, while the carbon fluxes at greater depths appear low and constant (Suess, 1980; Martin et al., 1987; Iversen et al., 2010). This indicates low remineralisation rates and/or increasing aggregate sinking velocities with depth. However, the importance of sinking velocity versus remineralisation for the POC fluxes at depth is still unclear.

Zooplankton concentrations decrease with increasing depth, suggesting that microbial degradation is the main degradation mechanism of settling aggregates in the deep ocean (Stemmann et al., 2004). Aggregate-associated microbes are exposed to high pressure and low temperature in the deep ocean compared to the surface ocean. Exposing shallow-water-adapted bacterial strains to hydrostatic 
pressure equivalent to $4000 \mathrm{~m}$ reduces the abundance, cell size, and activity for some strains, while others seem to have physiological pressure adaptations (Grossart and Gust, 2009; Tamburini et al., 2009; Nagata et al., 2010). Such adaptations might explain observations of living, active, surface-adapted, particle-associated bacteria at $6000 \mathrm{~m}$ depth (Eloe et al., 2011). Recent studies have observed limited exchange between aggregate-attached and free-living microbes through the water column (Delong et al., 2006; Aristegui et al., 2009). This supports laboratory observations of bacteria which became permanently attached to aggregates after becoming embedded in the matrix within aggregates (Kiørboe et al., 2002). Therefore, a large fraction of the aggregate-associated microbial community at depth may be made up by surface-oceanadapted microorganisms embedded within the aggregates.

Studies of the influence of elevated temperature on microbial activity showed increased microbial degradation of organic matter when exposing microbes to temperatures higher than their natural range (Hoppe et al., 2008; Piontek et al., 2009). However, data for the influence of low temperature on the activity of particle-attached, surface-adapted microbes sinking to the deep ocean is limited, though this knowledge would greatly improve our understanding of deep ocean carbon fluxes. While pressure increases linearly with depth, temperature changes often occur over steep gradients in the upper few hundred meters at low and mid-latitudes. This results in rapid temperature transitions over short time scales for aggregate-associated microbes sinking at $100 \mathrm{~m}$ per day or more, and, thus, transported from, e.g., $15^{\circ} \mathrm{C}$ to $4{ }^{\circ} \mathrm{C}$ within days. Therefore, direct studies of how a rapid temperature transition from $15^{\circ} \mathrm{C}$ to $4{ }^{\circ} \mathrm{C}$ affects the aggregate dynamics, activity of attached microbes, and aggregate sinking velocities are needed.

In the present study, we directly measured size-specific formation, degradation and sinking velocity of diatom aggregates over three weeks at $15^{\circ} \mathrm{C}$ and $4{ }^{\circ} \mathrm{C}$. Size, respiration rate, and sinking velocity of individual aggregates were measured in a vertical flow system in which aggregate sinking velocity was balanced by an upward-directed flow velocity. The fluid motion and solute distribution in the vicinity of the aggregates under these experimental conditions were equivalent to those in the vicinity of an aggregate sinking through the water column at a velocity equal to the water flow velocity (Kiørboe et al., 2001). The oxygen fluxes to such sinking aggregates were calculated from $\mathrm{O}_{2}$ concentration gradients measured at the aggregate-water interface using an $\mathrm{O}_{2}$ microsensor. These methods are non-destructive to the aggregates, which were afterwards collected for dry mass, POC, and PON analysis. We used our obtained laboratory data to calculate potential carbon fluxes in the deep cold ocean and compared them with those obtained from sediment traps in a global data set.

\section{Material and methods}

\subsection{Algae cultures}

Cultures of the diatom Skeletonema marinoi (formerly known as S. costatum; Sarno et al., 2005) from the North Sea were grown at $15^{\circ} \mathrm{C}$ in $0.2 \mu \mathrm{m}$ filtered seawater (salinity 32) enriched with nutrients according to $f / 2$ medium (Guillard, 1975) with silicate added at a concentration of $106 \mu \mathrm{M}$. The cultures were kept in a $12 \mathrm{~h}$ light period at $150 \mu \mathrm{mol}$ photons $\mathrm{m}^{-2} \mathrm{~s}^{-1}$, and allowed a growth period of 13 days, after which stationary growth phase was reached.

\subsection{Aggregate formation}

The diatom cultures were diluted with GF/F-filtered seawater (salinity 32) to a final concentration of $3 \times 10^{5}$ cells mL $^{-1}$ and incubated in $1.15 \mathrm{~L}$ Plexiglas roller tanks with diameters of $14 \mathrm{~cm}$ and depths of $7.47 \mathrm{~cm}$ to form aggregates. In total, 20 roller tank incubations were rotated on rolling tables at 3 rotations per minute (rpm) at $15^{\circ} \mathrm{C}$ in darkness. After three days of incubation, the temperature was lowered to $4^{\circ} \mathrm{C}$ for half of the roller tanks to imitate a rapid settling to the colder waters of the deep ocean. The aggregate dynamics were followed throughout the study by counting the aggregates within different size classes in each roller tank.

\subsection{Sinking velocity}

Individual aggregates were gently transferred with a widebore pipette from the roller tanks to a vertical flow system where the sinking velocity of each aggregate was measured (Ploug and Jørgensen, 1999; Ploug et al., 2010). Apart from being GF/F filtered, the water in the vertical flow system was similar to the water in the roller tanks (salinity 32 ), and the water temperature was adjusted accordingly to the treatment $\left(15\right.$ or $\left.4{ }^{\circ} \mathrm{C}\right)$. The flow was adjusted with a needle valve until the aggregate remained suspended at a distance of one aggregate diameter above the net, whereby the aggregate sinking velocity was balanced by the upward-directed seawater flow velocity (Ploug et al., 2010). The sinking velocity of an aggregate was calculated from the flow rate divided by the cross-sectional area of the flow chamber. Triplicate measurements of sinking velocity were made for each aggregate. The length of all three aggregate axes (x, y, and $\mathrm{z}$ direction) was measured in the flow system using a horizontal dissection microscope with a calibrated ocular. The aggregate volume was calculated by assuming an ellipsoid shape. For comparison with other aggregate shapes we calculated the equivalent spherical diameter (ESD) of each aggregate.

\subsection{Oxygen measurements}

Oxygen gradients at the aggregate-water interface were measured using a Clark-type oxygen microelectrode with a guard cathode (Revsbech, 1989) mounted in a micromanipulator 
and calibrated at air-saturation and at anoxic conditions. The electrode current was measured on a picoamperemeter (Unisense, PA2000) and read on a strip chart recorder (Kipp and Zonen) at high resolution $\left(2 \mu \mathrm{M} \mathrm{O}_{2} \mathrm{~cm}^{-1}\right)$. The tip diameter of the microsensor was $2 \mu \mathrm{m}$. The relative distance between the microelectrode tip and the aggregate surface was measured using a dissection microscope with a calibrated ocular micrometer. The $90 \%$ response time of the electrode was $<1 \mathrm{~s}$ and the stirring sensitivity $<0.3 \%$. The aggregates were suspended by an upward-directed flow that balanced the aggregate's sinking velocity in the same vertical net-jet flow system as used for estimating sinking velocities (Ploug and Jørgensen, 1999). All measurements were done at the steady state of the oxygen gradients. The water in the flow system ( $\mathrm{GF} / \mathrm{F}$ filtered seawater at 15 or $4{ }^{\circ} \mathrm{C}$ with a salinity of 32) was similar to the non-filter water in the roller tanks

\subsection{Calculations of respiration rates}

Oxygen fluxes and respiration rates were calculated from the oxygen gradients measured at the aggregate-water interface under steady-state conditions. The analytical solutions for oxygen distribution and diffusive fluxes at the aggregatewater interface were fitted to measured values by applying the solver routine of the spreadsheet program Excel version 2003 (Microsoft) as previously described (Ploug et al., 1997). We used temperature- and salinity-corrected oxygen diffusion coefficients of $1.22 \times 10^{-5} \mathrm{~cm}^{2} \mathrm{~s}^{-1}$ for $4^{\circ} \mathrm{C}$ and $1.72 \times 10^{-5} \mathrm{~cm}^{2} \mathrm{~s}^{-1}$ for $15^{\circ} \mathrm{C}$ in the calculations (Broecker and Peng, 1974). The surface area of ellipsoids (Maas, 1994) was used to calculate total oxygen consumption. The oxygen consumption rate was converted to carbon respiration assuming a respiratory quotient of $1 \mathrm{~mol} \mathrm{O}_{2}$ to $1 \mathrm{molCO}_{2}$, as also used in previous studies of $\mathrm{O}_{2}$ respiration and POC degradation in diatom aggregates (e.g. Ploug and Grossart, 2000).

\subsection{Aggregate dry weight and particulate organic carbon and nitrogen content}

The aggregate dry weight (DW) was determined by filtering single aggregates with known volumes onto pre-weighed $0.4 \mu \mathrm{m}$ polycarbonate filters. Each filter contained one aggregate, which was gently washed with de-ionised water, to remove salt, and dried at $60^{\circ} \mathrm{C}$ for $48 \mathrm{~h}$ before weighing on a Mettler Toledo (UMX 2) scale with a sensitivity of $0.1 \mu \mathrm{g}$.

The ratio of particulate organic carbon (POC) to DW was determined by filtering $\sim 50$ aggregates onto pre-weighed $25 \mathrm{~mm} \mathrm{GF/F} \mathrm{filters.} \mathrm{The} \mathrm{filters} \mathrm{were} \mathrm{gently} \mathrm{rinsed} \mathrm{with} \mathrm{de-}$ ionised water, and dried at $40^{\circ} \mathrm{C}$ for $48 \mathrm{~h}$ before being reweighed on a Mettler Toledo UMX2 balance (sensitivity: $0.1 \mu \mathrm{g}$ ). POC and PON contents of the aggregates on each filter were measured on an EA mass spectrometer (ANCA-SL 20 -20, Sercon Ltd. Crewe, UK) with a precision of $\pm 0.7 \mu \mathrm{g} \mathrm{C}$ or $0.3 \%$. At each time point, when measurements were performed, a POC to DW ratio and a POC to PON ratio were calculated for the measured treatment. This was calculated by dividing the amount of POC by the DW of the material on each filter and used to estimate POC content within the measured aggregate by multiplying its DW by the POC: DW ratio for that aggregate treatment and time point.

\subsection{Density of aggregates}

We used the Navier-Stokes drag equation to calculate the excess density $(\Delta \rho)$ of our aggregates (Stokes, 1851):

$\Delta \rho=\frac{C_{\mathrm{D}} \rho_{\mathrm{w}} w^{2}}{\frac{4}{3} g \mathrm{ESD}}$,

where $C_{\mathrm{D}}$ is the dimensionless drag force defined in Eq. (2), $\rho_{\mathrm{W}}$ is the density of seawater $\left(1.0237\right.$ and $1.0254 \mathrm{~g} \mathrm{~cm}^{-3}$, for a salinity of 32 at 15 and $4{ }^{\circ} \mathrm{C}$, respectively), $w$ is the measured sinking velocity in $\mathrm{cm} \mathrm{s}^{-1}, g$ is the gravitational acceleration of $981 \mathrm{~cm} \mathrm{~s}^{-2}$, and ESD is the equivalent spherical diameter in $\mathrm{cm}$. We calculated $C_{\mathrm{D}}$ using the drag equation for $R e>1$ given by White (1974):

$C_{\mathrm{D}}=\left(\frac{24}{R e}\right)+\left(\frac{6}{1+R e^{0.5}}\right)+0.4$,

where Reynolds number $(R e)$ was defined as

$R e=w \mathrm{ESD} \frac{\rho_{\mathrm{w}}}{\eta}$,

where $\eta$ is the dynamic viscosity $\left(1.2158 \times 10^{-2}\right.$ and $1.6498 \times 10^{-2} \mathrm{~g} \mathrm{~cm}^{-1} \mathrm{~s}^{-1}$, for a salinity of 32 at 15 and $4{ }^{\circ} \mathrm{C}$, respectively).

\subsection{Solid hydrated density of aggregate constitutes}

The solid hydrated density $\left(\rho s, \mathrm{~g} \mathrm{~cm}^{-3}\right)$ of the aggregates was determined in a density gradient using a modified version of previously reported methods (Schwinghamer, 1991; Feinberg and Dam, 1998). The density gradient consisted of seven dilutions which were made using Ludox TM colloidal silica, sucrose, and distilled water. The dilutions had a density range between 1.05 and $1.43 \mathrm{~g} \mathrm{~cm}^{-3}$. The dilutions were buffered to $\mathrm{pH} 8.1$ with $0.0125 \mathrm{M}$ Tris plus $0.0125 \mathrm{M}$ Tris$\mathrm{HCl}$ (final concentration). Thus, the produced gradient was iso-osmotic with seawater of a salinity of 32 . Two $\mathrm{mL}$ of each dilution were gently transferred to a $20 \mathrm{~mL}$ centrifuge tube with the densest dilution below and the least dense dilution on top. The density gradients were refrigerated overnight and allowed to adjust to the treatment temperature before use. One $\mathrm{mL}$ of seawater (salinity 32 ) was gently applied on top of each density gradient, and single aggregates were transferred to individual centrifugation tubes using a wide-tipped pipette letting the aggregates settle into the seawater layer without breaking. After a settling period of 2 to $4 \mathrm{~h}$, the density gradients were centrifuged at $3000 \mathrm{rpm}$ for $30 \mathrm{~min}$ to ensure that the aggregate had settled to the density layer equivalent to its solid hydrated density. One $\mathrm{mL}$ from the density 
layer containing the aggregate was removed from the tube, and its weight was measured on a Mettler Toledo fine balance. Assuming iso-osmotic conditions between the aggregate and the density solution, the density of the removed gradient layer represents the solid hydrated density of the aggregate having neutral buoyancy within it.

\subsection{Transparent exopolymer particles (TEP) measurements}

TEP concentrations within the aggregates were quantified using the dye-binding assay for spectrophotometric measurements (Passow and Alldredge, 1995). At each measuring point during the incubation period, three nucleopore polycarbonate filters $(0.4 \mu \mathrm{m})$ were prepared with one aggregate of known volume gently filtered onto each filter. TEPs were stained on the filters for 30 seconds with $500 \mu \mathrm{L}$ precalibrated $0.02 \%$ aqueous solution of alcian blue (8GX) in $0.06 \%$ acetic acid ( $\mathrm{pH} 2.5)$. The filters were rinsed once with distilled water to remove excess dye, and were submerged in sulfuric acid to dissolve the dye. The TEP concentration (Xantan equivalents) within each aggregate was estimated by measuring one $\mathrm{mL}$ of the solvent on a spectrophotometer at $787 \mathrm{~nm}$. The TEP concentration within each aggregate was determined via triplicate measurements of the solvent.

\section{Results}

\subsection{Aggregate formation}

Initial cell concentrations of $S$. marinoi in all 20 roller tanks were $3 \times 10^{5} \mathrm{~mL}^{-1}$, and aggregates were formed within the first $19 \mathrm{~h}$ of incubation. A general trend of increasing abundance of larger aggregate sizes concurrent with decreasing abundance of small aggregate sizes over time was observed, indicating that the large aggregates scavenged the small aggregates over time (Fig. 1). However, the aggregates in the $15^{\circ} \mathrm{C}$ treatment showed an increase in the abundance of small aggregates $(<3 \mathrm{~mm})$ and a decrease in the abundance of large aggregates $(>3 \mathrm{~mm})$ on day 12 , indicating that disaggregation of large aggregates occurred between day 9 and day 12 (Fig. 1a). Thereafter, the small aggregates reaggregated and/or were scavenged by the larger aggregates, which resulted in continuous increasing maximum aggregate size. The aggregates incubated at $4{ }^{\circ} \mathrm{C}$ did not show any indication of disaggregation, but had continuously increasing abundance of larger aggregates concurrent with decreasing abundance of small aggregates (Fig. 1b). This was due to constant scavenging of small aggregates by large aggregates throughout the study. We observed aggregates larger than $10 \mathrm{~mm}$ in the roller tanks at both temperatures, but those aggregates were very fragile and fell apart during sampling; therefore no measurements were performed on aggregates larger than $\sim 7 \mathrm{~mm}$.
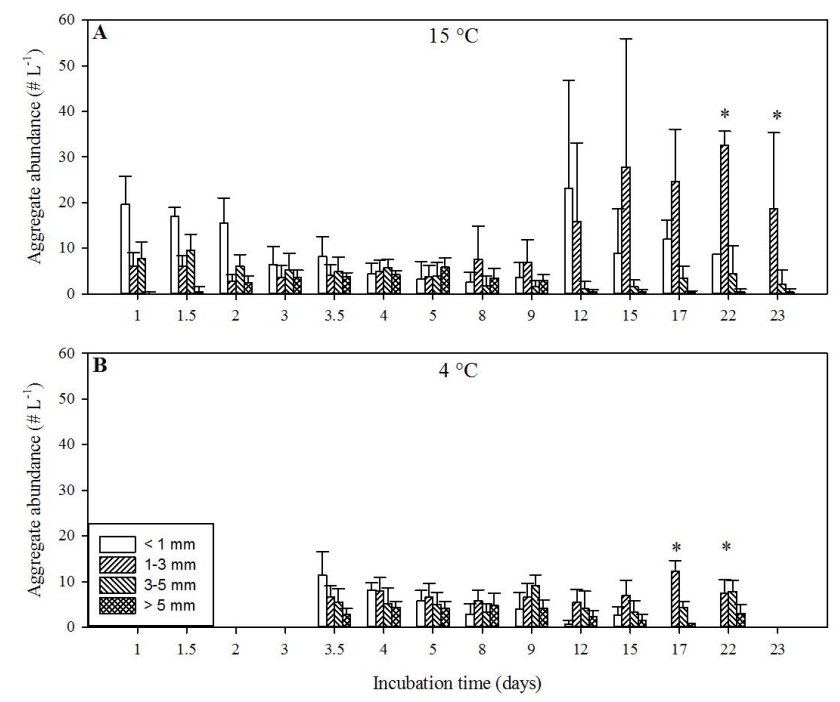

Fig. 1. Aggregate evolution over time for the 15 and $4{ }^{\circ} \mathrm{C}$ treatments in the upper and lower panel, respectively. The aggregates in the $4{ }^{\circ} \mathrm{C}$ treatment were kept at $15^{\circ} \mathrm{C}$ during the first 3 days of incubation. The aggregates were pooled into size classes and counted by eye (MHI) at the different time points during the whole incubation period, and should, thus, be viewed as semi-quantitative measurements. The results give good indications of disaggregation during the incubation period, but the actual aggregate abundances are not absolute values, especially not at high abundances. The asterisks at the last two measured time points in each treatments indicate that only replicate measurements were done, but standard deviations are still plotted to indicate the variation in size distribution in the two roller tanks.

\subsection{Aggregate dry weight}

The dry weight (DW) increased with increasing aggregate size for both the aggregates incubated in the 15 and $4{ }^{\circ} \mathrm{C}$ treatments (Fig. 2a and e). A tendency of higher variation in size-specific aggregate DW over time was observed for the aggregates incubated at $15^{\circ} \mathrm{C}$ compared to those transferred to $4^{\circ} \mathrm{C}$. This was due to a tendency of higher sizespecific DW for the 1-, 17-, and 23-day-old aggregates in the $15^{\circ} \mathrm{C}$ treatment (Fig. 2b). No changes in size-specific DW over time were observed among the aggregates transferred to $4{ }^{\circ} \mathrm{C}$ with the exception of day 15 where aggregates seemed to have higher size-specific DW compared to the other time points in treatment $4{ }^{\circ} \mathrm{C}$ (Fig. 2f). However, this was mainly driven by one $3.5 \mathrm{~mm}$ aggregate weighing two times more than similarly sized aggregates measured on day 15 (Fig. 2e).

\subsection{Aggregate excess density and hydrated solid density}

Due to the fractal nature of aggregates, their excess densities decrease with increasing size; i.e., their porosity increases with increasing aggregate size. The excess densities did not change over time in the $4{ }^{\circ} \mathrm{C}$ treatment, but increased in the $15^{\circ} \mathrm{C}$ treatments after day 17 and remained high until the 

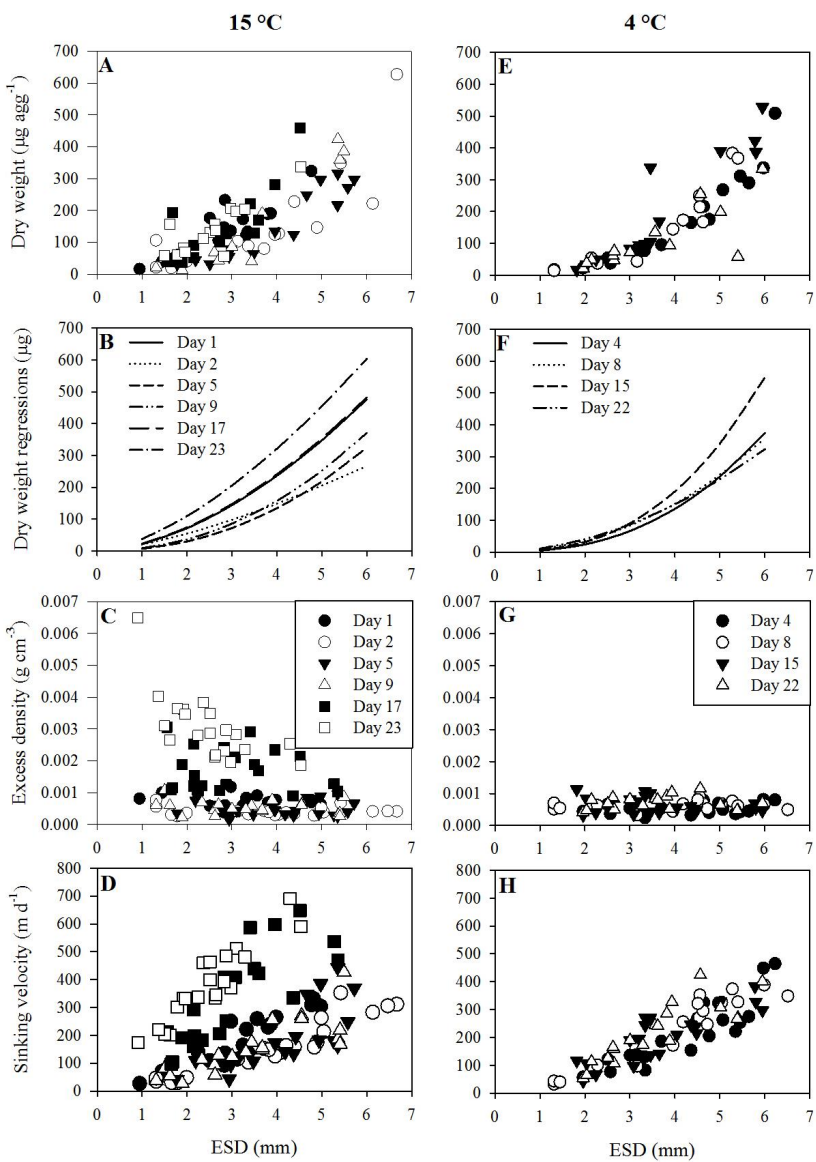

Fig. 2. Aggregate dry weight (A, E), dry weight power regressions $(\mathbf{B}, \mathbf{F})$, excess density $(\mathbf{C}, \mathbf{G})$, and sinking velocity $(\mathbf{D}, \mathbf{H})$ plotted against aggregate equivalent spherical diameter (ESD) for the 15 and $4{ }^{\circ} \mathrm{C}$ treatments. The symbols for the day of the different measurements are given in the legends. The legend for the $15^{\circ} \mathrm{C}$ treatment $(\mathbf{A}, \mathbf{B}, \mathbf{C}, \mathbf{D})$ is given in graph $(\mathbf{C})$ and the legend for the $4{ }^{\circ} \mathrm{C}$ treatment $(\mathbf{E}, \mathbf{F}, \mathbf{G}, \mathbf{H})$ is given in graph $(\mathbf{G})$.

last measurement on day 23 (Fig. 2c). The solid hydrated density of the aggregated material ranged between 1.10 and $1.18 \mathrm{~g} \mathrm{~cm}^{-3}$ and showed no significant differences within or between the 4 and $15^{\circ} \mathrm{C}$ treatments (One Way ANOVA; $p>0.38$ ); we have therefore averaged the solid hydrated density of the aggregated material over the entire incubation time for each treatment (Table 1). The constant solid hydrated density during the incubation period shows that the increasing size-specific excess density in the $15^{\circ} \mathrm{C}$ treatment after day 17 (Fig. 2c) was not due to a density change of the composite particles within the aggregates, but rather due to an increased compactness of the aggregated material. This is also supported by the increase in size-specific DW after day 17 (Fig. 2a).

\subsection{Aggregate sinking velocity}

Sinking velocity increased nearly linearly with increasing aggregate size in both the 4 and $15^{\circ} \mathrm{C}$ treatments (Fig. $2 \mathrm{~d}$ and h). Lowering the temperature from $15^{\circ} \mathrm{C}$ to $4{ }^{\circ} \mathrm{C}$ for half of the roller tanks after three days of incubation had no effect on the size-specific sinking speeds, and no significant difference was observed in size-specific sinking speed between the $15^{\circ} \mathrm{C}$ (day 2 and 5) and the $4{ }^{\circ} \mathrm{C}$ (day 4) treatments (one-way ANCOVA, $p>0.1)$. The aggregates in the $4{ }^{\circ} \mathrm{C}$ treatment did not show any significant changes in size-specific sinking velocity over time (Fig. $2 \mathrm{~h}$; one-way ANCOVA, $p>0.3$ ). The $15{ }^{\circ} \mathrm{C}$ treatment had similar size-specific sinking speeds between day 2 and day 9, but we measured significantly increased size-specific sinking speeds on day 17 and day 23 (Fig. 2d; one-way ANCOVA, $p<0.01$ ). This increase in size-specific sinking speeds coincided with the increase in size-specific excess density (Fig. 2c) and size-specific DW (Fig. 2a) and occurred at the first sampling after the disaggregation event on day 12 (Fig. 1a).

\subsection{Particulate organic carbon and nitrogen content, and respiration rate}

Particulate organic carbon (POC) content in the aggregates increased with increasing aggregate size in both the 4 and $15^{\circ} \mathrm{C}$ treatments (Fig. 3a and d). There was no significant difference in the average POC: DW ratio over the entire incubation time between or within the two treatments (Table 1; Student's $t$ test; $p>0.7)$. The respiration rate per aggregate increased with increasing aggregate size at both 4 and $15^{\circ} \mathrm{C}$, but the size-specific respiration rate was generally higher in the $15^{\circ} \mathrm{C}$ treatment compared to that in the $4{ }^{\circ} \mathrm{C}$ treatment (data not shown). The respiration rate increased proportionally to POC content of the aggregates in the two treatments, indicating first-order kinetics of POC degradation at both temperatures (Fig. $3 \mathrm{~b}$ and e). The carbon-specific respiration rate was calculated by dividing the carbon respiration rate with the total POC content of each aggregate and was size-independent in both treatments at all times (Fig. 3c and f). The overall average carbon-specific respiration rates were $0.12 \pm 0.03 \mathrm{~d}^{-1}$ and $0.03 \pm 0.01 \mathrm{~d}^{-1}$ in the $15^{\circ} \mathrm{C}$ and $4{ }^{\circ} \mathrm{C}$, respectively. Hence, the average carbon-specific respiration rate was 3.5 -fold lower in the $4{ }^{\circ} \mathrm{C}$ treatment compared to that in the $15^{\circ} \mathrm{C}$ treatment (Table 1; Student's $t$ test; $p<0.01$ ). The slight tendency for increasing average carbon-specific degradation rates over time in the $4{ }^{\circ} \mathrm{C}$ treatment and decreasing average carbon-specific degradation rates over time in the $15^{\circ} \mathrm{C}$ treatment were not statistically significant (Student's $t$ test; $p>0.1$ ) (Fig. 4a). The tendency of increasing $\mathrm{C}: \mathrm{N}$ ratio at day 23 in the $15{ }^{\circ} \mathrm{C}$ treatment could not be tested statistically since the $\mathrm{POC}$ and particulate organic nitrogen only were measured from one filter due to limited amount of material, and, therefore, the $\mathrm{C}: \mathrm{N}$ ratios should be treated with care. 
Table 1. Average (Av.) measurements for Xanthan equivalent ( $\mu$ g Xequv) TEP content to dry weight (DW) ratio, solid hydrated density of the composite particles within the aggregates, POC content to DW ratio, POC content to PON content ratio, and carbon-specific respiration rate (C-spec. deg.) for the 15 and $4{ }^{\circ} \mathrm{C}$ treatment over the whole incubation period. Standard deviations are presented together with average values. There were only significant differences in the average values for carbon-specific respiration rate between the two treatments.

\begin{tabular}{llllll}
\hline Treatment & $\begin{array}{l}\text { Av. TEP : DW } \\
\left(\mu \mathrm{g} \text { Xequv TEP } \mu \mathrm{g} \mathrm{Agg}^{-1}\right)\end{array}$ & $\begin{array}{l}\text { Av. solid hydr. density } \\
\left(\mathrm{g} \mathrm{cm}^{-3}\right)\end{array}$ & $\begin{array}{l}\text { Av. POC: DW } \\
\left(\mu \mathrm{g} \text { POC } \mu g \mathrm{Agg}^{-1}\right)\end{array}$ & $\begin{array}{l}\text { Av. POC: PON } \\
\left(\mu g \text { POC } \mu \mathrm{gON}^{-1}\right)\end{array}$ & $\begin{array}{l}\text { Av. C-spec. deg. } \\
\left(\mathrm{d}^{-1}\right)\end{array}$ \\
\hline $15^{\circ} \mathrm{C}$ & $0.035 \pm 0.008$ & $1.15 \pm 0.02$ & $0.25 \pm 0.02$ & $5.28 \pm 0.47$ & $0.12 \pm 0.03^{*}$ \\
$4{ }^{\circ} \mathrm{C}$ & $0.036 \pm 0.005$ & $1.14 \pm 0.02$ & $0.25 \pm 0.01$ & $5.02 \pm 0.21$ & $0.03 \pm 0.01^{*}$ \\
\hline
\end{tabular}

* Significant difference between the 15 and $4^{\circ} \mathrm{C}$ treatment (Student's $t$ test; $p=0.01$ ).
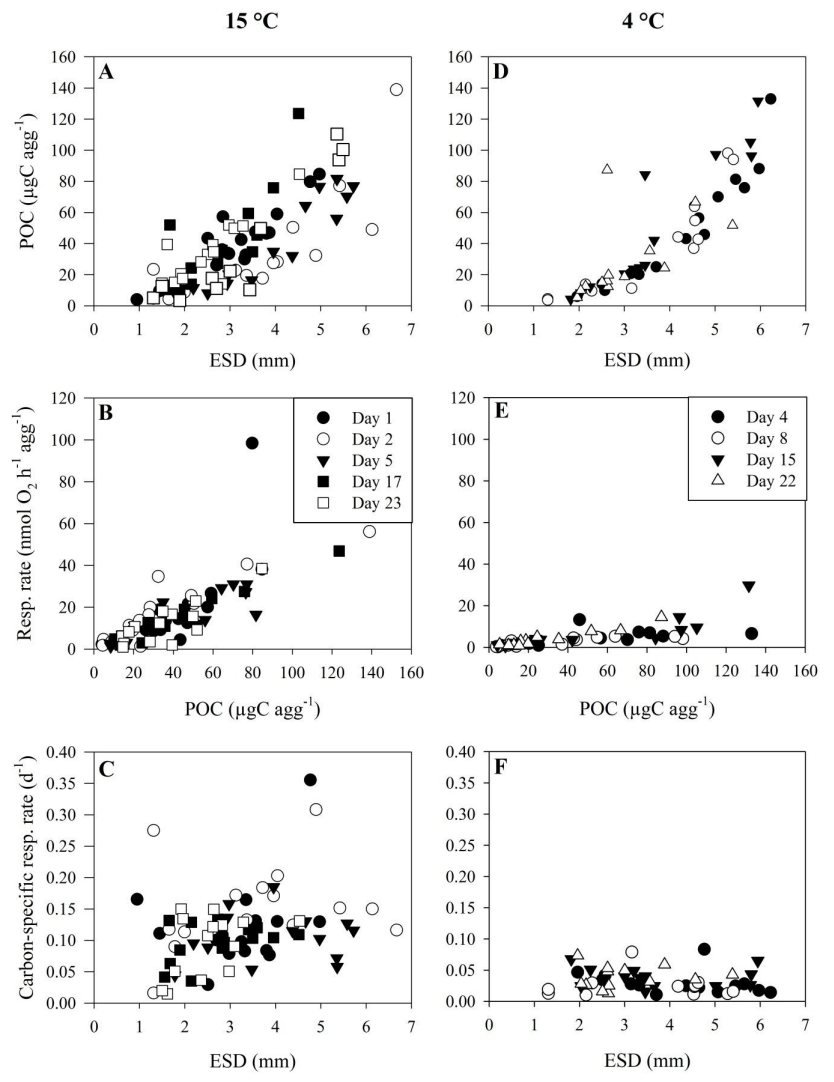

Fig. 3. Aggregate particulate organic carbon (POC) content is plotted against aggregate equivalent spherical diameter (ESD) (A, D), the respiration rate (Resp. rate) of the microbial community attached to each aggregate is plotted against the POC content of the aggregates $(\mathbf{B}, \mathbf{E})$, and the carbon-specific respiration rate within each aggregate is plotted against the ESD of the aggregates $(\mathbf{C}, \mathbf{F})$. The symbols for the day of the different measurements are given in the legends. The legend for the $15^{\circ} \mathrm{C}$ treatment $(\mathbf{A}, \mathbf{B}, \mathbf{C})$ is given in graph (B) and the legend for the $4{ }^{\circ} \mathrm{C}$ treatment $(\mathbf{D}, \mathbf{E}, \mathbf{F})$ is given in graph $(\mathbf{E})$.

\subsection{Aggregate TEP content}

The content of transparent exopolymer particles (TEP) within the aggregates in both treatments was low but increased with increasing aggregate size from $\sim 0.3 \mu \mathrm{g}$ TEP
(Xanthan equivalents) in 1-mm-large aggregates and $\sim 8 \mu \mathrm{g}$ TEP (Xanthan equivalents) in 5-mm-large aggregates. The average TEP content to dry weight ratio of the aggregates was low and constant throughout the study (Fig. 4c). No significant differences were observed in the TEP content to aggregate dry weight ratio over time within the 15 or $4{ }^{\circ} \mathrm{C}$ treatments or between the two treatments (One-way ANOVA; $p>0.2$, Fig. $4 c$ and Table 1).

\section{Discussion}

There were no significant changes in size distribution of aggregates transitioned to $4{ }^{\circ} \mathrm{C}$ compared to the aggregates kept at $15^{\circ} \mathrm{C}$ (Fig. 1). This indicated that the temperature change did not influence the physical structure of the aggregates, which was also evident from the lack of changes in sizespecific dry weight, excess density, and sinking velocity between the two temperature treatments between day 4 and 9 (Fig. 2). This shows that temperature changes alone do not influence aggregation and disaggregation processes.

Our measurements of respiration represent community respiration on aggregates; i.e., it includes respiration by diatoms and associated bacteria and protozoa. The average carbon-specific respiration rates measured in aggregates at $15^{\circ} \mathrm{C}$ were similar to previous rates measured within marine snow, phytoplankton aggregates, and copepod fecal pellets at surface water conditions (Ploug et al., 1999; Iversen et al., 2010; Iversen and Ploug, 2010). The potential fluxes of $\mathrm{O}_{2}$ due to advection and diffusion to sinking aggregates has earlier been shown to be similar at 4 and $20^{\circ} \mathrm{C}$ because the lower diffusivity and higher kinematic viscosity is compensated by higher $\mathrm{O}_{2}$ solubility at lower temperatures as compared to higher temperatures (Ploug, 2001). The carbon-specific community respiration rates in diatom aggregates measured at $4{ }^{\circ} \mathrm{C}$ as compared to those measured at $15^{\circ} \mathrm{C}$ were similar to those expected for a $Q_{10}$ of 3.3 , which has been measured previously with respect to aquatic bacterial growth rates in pelagic habitats (White et al., 1991). Hence, the measured decrease in community respiration rate was presumably due to lower cell-specific activities within the aggregates. Decreased ambient temperatures, therefore, significantly reduce the organic carbon remineralisation by microbiota adapted to 

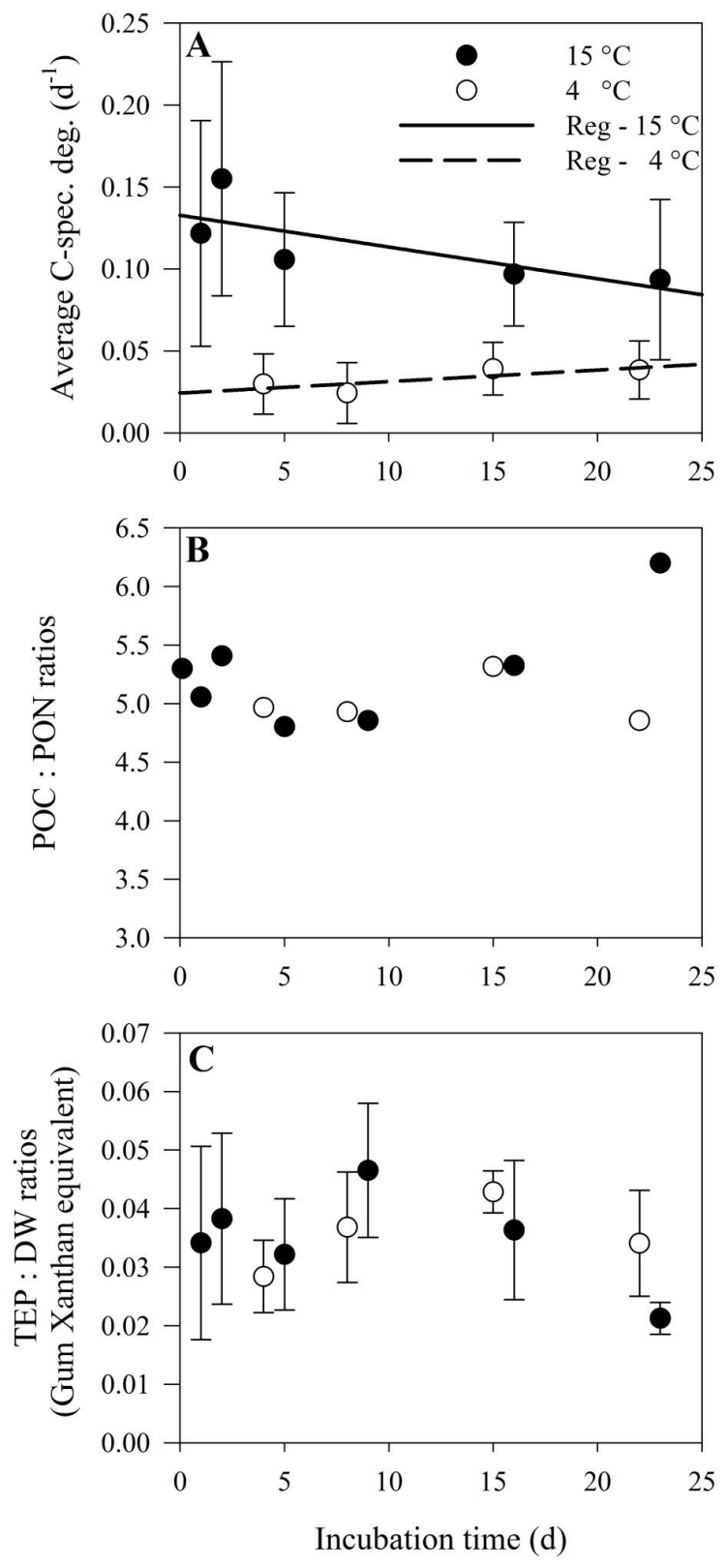

Fig. 4. Average carbon-specific respiration rate (Average C-spec. deg.) (A), particulate organic carbon to particulate organic nitrogen ratio (POC: PON ratios) (B), and transparent exopolymer particles to dry weigth ratios (TEP : DW ratios) $(\mathbf{C})$ is plotted against the incubation time for both the 15 and $4{ }^{\circ} \mathrm{C}$ treatments as solid and open circles, respectively. Standard deviations are indicated in the plot when available.

higher temperatures, e.g. if surface-ocean-adapted microbes attached to settling aggregates are transported to the colder deep ocean. Kiørboe et al. (2002) suggested that detachment of bacteria from aggregates is only physically possible soon after attachment because the bacteria may become embedded in the mucus or matrix within the aggregates and, thus, permanently attached. This may explain observations of dif- ferent prokaryotic communities within aggregates compared to the free water (Moeseneder et al., 2001) and observations of living surface ocean microbes attached to aggregates collected at $6000 \mathrm{~m}$ (Eloe et al., 2011).

Our experimental set-up excluded changing hydrostatic pressure, and thus did not fully reflect true in situ conditions. Hydrostatic pressure has been suggested to be an important environmental parameter influencing microbial dynamics within aggregates (Tamburini et al., 2003, 2006; Grossart and Gust, 2009). Grossart and Gust (2009) showed that increasing hydrostatic pressure at constant temperature reduces bacterial cell size and abundance and can select for species with physiological pressure adaptations. Thus, pressure may also have an effect on microbial turnover of organic matter. This calls for experiments simultaneously investigating the influence from pressure and temperature changes on depthspecific degradation and export processes.

The POC : PON ratio remained relatively stable during our experiment, implying that POC and PON were degraded at similar rates. This has also been observed during the first 3 weeks in other degradation studies of diatom aggregates and other detritus where budgets of POC and PON degradation and $\mathrm{C}: \mathrm{N}$ ratios were measured (Ploug and Grossart, 2000; Verity et al., 2000; Grossart and Ploug, 2001). We observed high carbon-specific respiration rates at $15^{\circ} \mathrm{C}$ but no change in size-specific POC or DW content over time. This suggests that aggregates are primarily degraded outside-in, which has also been observed earlier (Ploug and Grossart, 2000). Furthermore, continuous scavenging of POC from the surrounding water, likely as suspended diatom cells, or DOC diffusing from the bulk towards aggregates were presumably additional carbon sources to support respiration in aggregates. Efficient scavenging of suspended particles by settling aggregates has been observed in situ (Brzezinski and Nelson, 1995; Kumar et al., 1998; Passow et al., 2001) and may be common in surface waters with high ambient particle concentrations. Thus, scavenging of suspended cells may support substrate for rapid turnover of POC by aggregateassociated microbes.

We calculated Reynolds numbers of less than 1 for aggregates smaller than $2 \mathrm{~mm}$ and an average of $10 \pm 6$ for larger aggregates. Hence, the sinking speeds were mainly controlled by inertial forces. Intuitively the higher water viscosity at $4{ }^{\circ} \mathrm{C}$ compared to $15^{\circ} \mathrm{C}$ should decrease the size-specific sinking speeds, but the temperature difference showed no immediate significant effect on the measured sinking speeds. Using Stokes' Law and Navier-Stokes drag equation, we calculated 27 and $22 \%$ lower sinking speeds, respectively, at $4{ }^{\circ} \mathrm{C}$ compared to $15^{\circ} \mathrm{C}$. Often the sinking speed of individual similarly sized aggregates varied with more than $50 \%$, and may have masked any potential temperature effect. Large scatter in size-specific sinking speeds of marine snow is common for both in situ and laboratory-produced aggregates due to their highly heterogeneous and porous nature (Alldredge and Gotschalk, 
1988; Iversen and Ploug, 2010), complicating predictions of in situ temperature-dependent settling.

The $15^{\circ} \mathrm{C}$ treatment showed significantly higher sizespecific sinking velocities and excess density on day 12 and onwards compared to the measurements before day 12 (Fig. 2c and d), coinciding with a disaggregation event between day 9 and 12 (Fig. 1a). The solid matter density of the composite particles within the aggregates, however, did not change over time in the two treatments (Table 1), indicating that the increase in size-specific excess density and sinking velocity was due to a more compact packaging of the composite particles within the aggregates after the disaggregation. Ploug et al. (2008) also observed an increase in excess density of $S$. marinoi aggregates due to increased compactness over time. Aggregates descending in situ encounter and scavenge small and dense particles (Kepkay, 1994). This may ballast the aggregates and increase their size-specific sinking velocities and excess densities over time (Ploug et al., 2008; Iversen et al., 2010; Iversen and Ploug, 2010).

One may speculate on the reasons for an increase in the aggregate compactness. The lack of changes in POC:DW, TEP:ESD, and solid hydrated density throughout the study suggests that the increased compactness cannot be explained by remineralisation of relatively buoyant organic material. The size-specific dry weight and excess density of the aggregates increased after the disaggregation event, as observed on day 17 and 23 at $15^{\circ} \mathrm{C}$ (Fig. $2 \mathrm{~b}$ and c). Moriceau et al. (2009) suggested that box-shaped diatom frustules might open due to silica dissolution. It is therefore likely that the 3.5 -foldhigher carbon-specific degradation rates at $15^{\circ} \mathrm{C}$ compared to $4{ }^{\circ} \mathrm{C}$ caused the frustules of the diatoms within the aggregates to open up and fall apart, explaining the observed disaggregation at $15^{\circ} \mathrm{C}$. This also implies that the individual diatom cells in the roller tanks at $15^{\circ} \mathrm{C}$ had a smaller cell size and possibly shorter chain length after day 9. Therefore, the re-aggregation and scavenging of the shorter diatom cell chains and smaller diatom cell sizes would form denser aggregates as compared to the aggregates measured before the disaggregation, since smaller particle sizes can be packed more compact within an aggregate. The absence of disaggregation at $4{ }^{\circ} \mathrm{C}$ indicates that the low microbial activity did not lead to opening of the diatom frustules.

To test how the carbon-specific respiration rates measured at 4 and $15^{\circ} \mathrm{C}$ match the attenuation of carbon fluxes in the deep ocean, we selected deep ocean carbon fluxes from global data sets of sediment trap studies (Table 1 in Lutz et al., 2002, and Table 3 in Honjo et al., 2008). We only included sediment trap studies with two different collection depths from the same study area and time and with an upper trap depth below $900 \mathrm{~m}$ (see Table 2). The carbon flux to a lower sediment trap $\left(T_{\mathrm{L}}\right)$ was calculated using $L$ ratios found for $4{ }^{\circ} \mathrm{C}$ and $15^{\circ} \mathrm{C}$, the collected carbon flux in an upper trap $\left(T_{\mathrm{U}}\right)$, and the depth interval between the two traps $(\Delta z)$ :
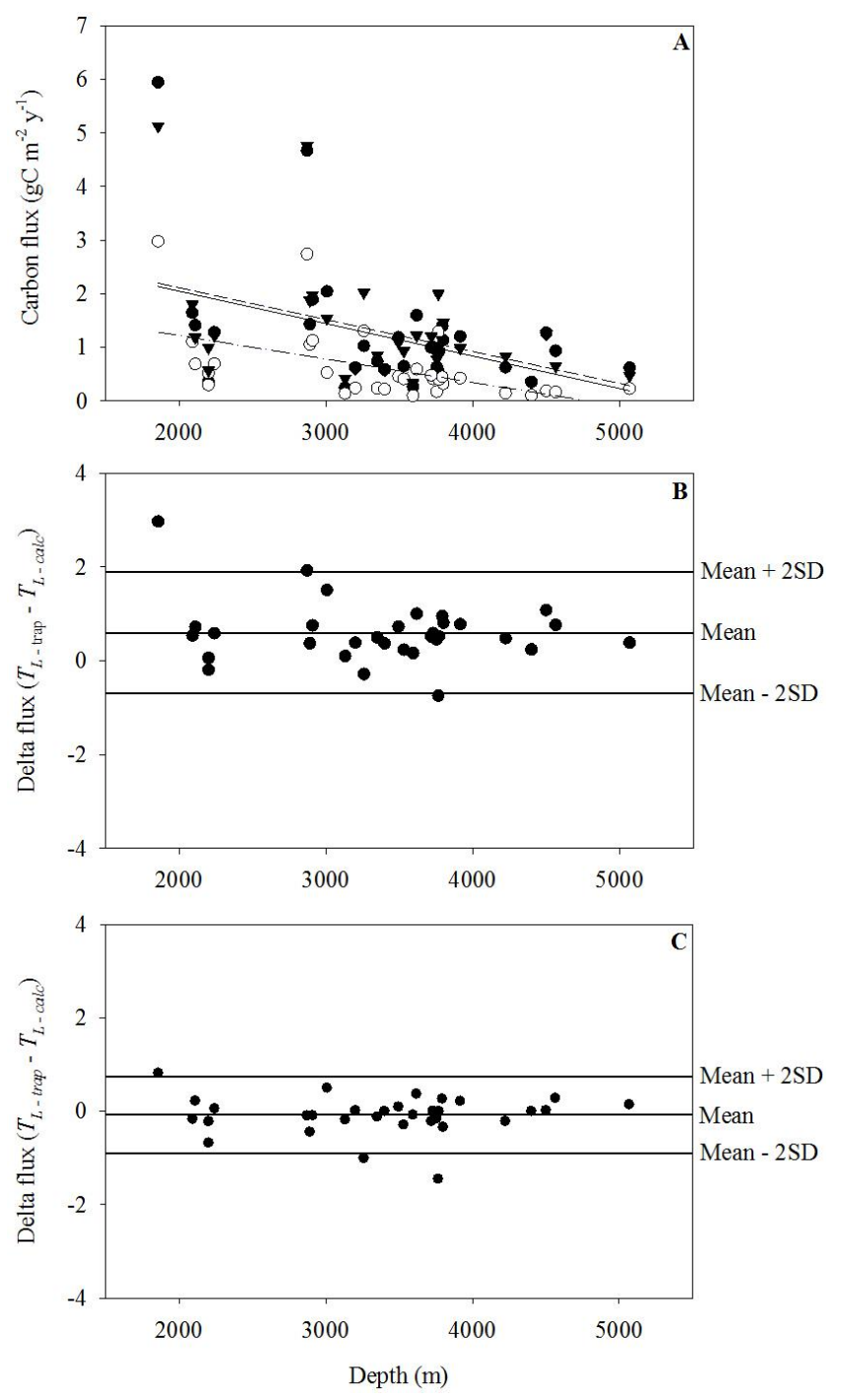

Fig. 5. (A) Carbon fluxes collected with deep ocean sediment traps (closed circles) and calculated using Eq. (4) for average carbonspecific respiration rates found for the $15^{\circ} \mathrm{C}$ treatment (open circles) and the $4{ }^{\circ} \mathrm{C}$ treatment (closed triangulars) - see text and Table 2 . The fluxes are plotted against the depth of the trap position. Linear regressions are fitted to each data set: Sediment trap collections: $y=3.26-0.0006 x$, and $R^{2}=0.16 ; 15^{\circ} \mathrm{C}$ treatment: $y=2.1-0.0004 x$, and $R^{2}=0.26$; and $4{ }^{\circ} \mathrm{C}$ treatment: $y=3.3-$ $0.0006 x$, and $R^{2}=0.19$. (B) Delta flux for the $15^{\circ} \mathrm{C}$ treatment calculated as trap carbon flux ( $\left.T_{\mathrm{L}-\text { trap}}\right)$ minus calculated carbon flux $\left(T_{\mathrm{L}-\mathrm{calc}}\right)$ and plotted against depth. Delta flux shows the error between the measured and calculated carbon fluxes: if the mean goes through zero, then the calculated flux returns that of the measured flux. Lines for mean and mean \pm standard deviation are provided in the plot. (C) Delta flux for the $4{ }^{\circ} \mathrm{C}$ treatment calculated as trap carbon flux $\left(T_{\mathrm{L}-\text { trap }}\right)$ minus calculated carbon flux $\left(T_{\mathrm{L} \text {-calc }}\right)$ and plotted against depth. Lines for mean and mean \pm standard deviation are provided in the plot. 
Table 2. Sediment-trap-derived annual flux to depth selected from Table 1 in Lutz et al. (2002) and Table 3 in Honjo et al. (2008); the data from the latter is indicated with an asterisk. The fluxes are calculated for the lower sediment traps using Eq. (4) and the carbon-specific degradation rates found from the $4{ }^{\circ} \mathrm{C}\left(T_{\mathrm{L}} 4^{\circ} \mathrm{C}\right)$ and the $15^{\circ} \mathrm{C}\left(T_{\mathrm{L}} 15^{\circ} \mathrm{C}\right)$ treatment. An average sinking velocity of $150 \mathrm{~m} \mathrm{~d}{ }^{-1}$ was used in both treatments to find $L$ from the average carbon-specific respiration rates for each treatment (Table 1).

\begin{tabular}{|c|c|c|c|c|c|c|}
\hline Region & $\begin{array}{l}\text { Trap ID/ } \\
\text { Year }\end{array}$ & $\begin{array}{l}\text { Depth } \\
(\mathrm{m})\end{array}$ & $\begin{array}{l}\text { Flux } \\
\left(\mathrm{g} \mathrm{m}^{-2} \mathrm{yr}^{-1}\right)\end{array}$ & References & $\begin{array}{l}T_{\mathrm{L}} 15^{\circ} \mathrm{C} \\
\left(\mathrm{g} \mathrm{m}^{-2} \mathrm{yr}^{-1}\right)\end{array}$ & $\begin{array}{l}T_{\mathrm{L}} 4^{\circ} \mathrm{C} \\
\left(\mathrm{g} \mathrm{m}^{-2} \mathrm{yr}^{-1}\right)\end{array}$ \\
\hline \multicolumn{7}{|l|}{ Polar Arctic } \\
\hline Greenland Sea & $88-89$ & 1000 & 1.2994 & Bodungen et al. (1995) & & \\
\hline Greenland Sea & & 2200 & 0.3285 & Bodungen et al. (1995) & 0.52 & 1.00 \\
\hline Greenland Sea & $90-91$ & 1000 & 0.74825 & Bodungen et al. (1995) & & \\
\hline Greenland Sea & & 2200 & 0.36135 & Bodungen et al. (1995) & 0.30 & 0.58 \\
\hline \multicolumn{7}{|l|}{ Atlantic Ocean } \\
\hline$N A B E$ & $89-90$ & 1110 & 1.47825 & Honjo and Manganini (1993) & & \\
\hline$N A B E$ & & 2110 & 1.41255 & Honjo and Manganini (1993) & 0.69 & 1.19 \\
\hline$N A B E$ & & 3730 & 1.0001 & Honjo and Manganini (1993) & 0.41 & 0.99 \\
\hline Eq. Atlantic & $92-94$ & 1000 & 2.6864 & Usbeck (1999) & & \\
\hline Eq. Atlantic & & 4500 & 1.2702 & Usbeck (1999) & 0.19 & 1.25 \\
\hline Eq. Atlantic & & 1833 & 2.36155 & Usbeck (1999) & & \\
\hline Eq. Atlantic & & 2890 & 1.4308 & Usbeck (1999) & 1.05 & 1.87 \\
\hline$*$ Atlantic & 92 & 2030 & 1.296 & Kuss and Kremling (1999) & & \\
\hline *Atlantic & & 3530 & 0.648 & Scholten et al. (2001) & 0.41 & 0.93 \\
\hline *Atlantic & 89 & 2018 & 1.752 & Honjo $(1992,1993)$ & & \\
\hline *Atlantic & & 3718 & 0.996 & Honjo $(1992,1993)$ & 0.48 & 1.21 \\
\hline *Atlantic & 89 & 2067 & 1.128 & Honjo $(1992,1993)$ & & \\
\hline *Atlantic & & 4563 & 0.936 & Honjo $(1992,1993)$ & 0.17 & 0.65 \\
\hline *Atlantic & $84+$ & 1500 & 0.876 & Deuser et al. (1995) & & \\
\hline$*$ Atlantic & $84+$ & 3200 & 0.624 & Conte et al. (2001) & 0.24 & 0.60 \\
\hline *Atlantic & 91 & 1600 & 0.864 & Fischer and Wefer (1996) & & \\
\hline *Atlantic & 91 & 3400 & 0.588 & Wefer and Fischer (1993) & 0.22 & 0.58 \\
\hline Subtrop. Atlantic & $77-78$ & 988 & 1.4381 & Honjo (1980) & & \\
\hline Subtrop. Atlantic & & 3755 & 0.63145 & Honjo (1980) & 0.17 & 0.78 \\
\hline Subtrop. Atlantic & & 5068 & 0.6205 & Honjo (1980) & 0.23 & 0.47 \\
\hline \multicolumn{7}{|l|}{ Pacific Ocean } \\
\hline Ocean station & $83-93$ & 1000 & 2.7083 & Wong et al. (1999) & & \\
\hline Ocean station & $82-93$ & 3800 & 1.1315 & Wong et al. (1999) & 0.32 & 1.47 \\
\hline South China Sea & $90-95$ & 1200 & 1.533 & Jianfang et al. (1998) & & \\
\hline South China Sea & & 2240 & 1.28115 & Jianfang et al. (1998) & 0.69 & 1.22 \\
\hline South China Sea & & 3770 & 0.9198 & Jianfang et al. (1998) & 0.40 & 0.40 \\
\hline South China Sea & $87-88$ & 1000 & 1.4308 & Jianfang et al. (1998) & & \\
\hline South China Sea & & 3350 & 0.7373 & Jianfang et al. (1998) & 0.23 & 0.85 \\
\hline NEq. Current & $88-89$ & 1130 & 0.6497 & Kempe and Knaack(1996) & & \\
\hline NEq. Current & & 3130 & 0.24455 & Kempe and Knaack(1996) & 0.14 & 0.42 \\
\hline Eq. Pacific & & 1600 & 0.8687 & Dymond and Collier (1988) & & \\
\hline Eq. Pacific & & 3400 & 0.5913 & Dymond and Collier (1988) & 0.22 & 0.59 \\
\hline Eq. Pacific & $92-93$ & 2250 & 0.5548 & Honjo et al. (1995) & & \\
\hline Eq. Pacific & & 4400 & 0.3504 & Honjo et al. (1995) & 0.11 & 0.35 \\
\hline Eq. Pacific & $92-93$ & 1191 & 2.1973 & Honjo et al. (1995) & & \\
\hline Eq. Pacific & & 2091 & 1.6425 & Honjo et al. (1995) & 1.11 & 1.80 \\
\hline Eq. Pacific & & 3793 & 1.4016 & Honjo et al. (1995) & 0.45 & 1.13 \\
\hline Eq. Pacific & $83-84$ & 1895 & 1.55125 & Dymond and Collier (1988) & & \\
\hline Eq. Pacific & & 3495 & 1.1899 & Dymond and Collier (1988) & 0.46 & 1.09 \\
\hline Eq. Pacific & $84-85$ & 1883 & 2.4747 & Dymond and Collier (1988) & & \\
\hline Eq. Pacific & & 2908 & 1.8907 & Dymond and Collier (1988) & 1.13 & 1.98 \\
\hline Eq. Pacific & & 2284 & 1.63885 & Honjo et al. (1995) & & \\
\hline Eq. Pacific & & 3618 & 1.5987 & Honjo et al. (1995) & 0.59 & 1.22 \\
\hline
\end{tabular}


Table 2. Continued.

\begin{tabular}{|c|c|c|c|c|c|c|}
\hline Region & $\begin{array}{l}\text { Trap ID/ } \\
\text { Year }\end{array}$ & $\begin{array}{l}\text { Depth } \\
(\mathrm{m})\end{array}$ & $\begin{array}{l}\text { Flux } \\
\left(\mathrm{g} \mathrm{m}^{-2} \mathrm{yr}^{-1}\right)\end{array}$ & References & $\begin{array}{l}T_{\mathrm{L}} 15^{\circ} \mathrm{C} \\
\left(\mathrm{g} \mathrm{m}^{-2} \mathrm{yr}^{-1}\right)\end{array}$ & $\begin{array}{l}T_{\mathrm{L}} 4^{\circ} \mathrm{C} \\
\left(\mathrm{g} \mathrm{m}^{-2} \mathrm{yr}^{-1}\right)\end{array}$ \\
\hline Eq. Pacific & $92-93$ & 1292 & 0.5548 & Honjo et al. (1995) & & \\
\hline Eq. Pacific & & 3594 & 0.2628 & Honjo et al. (1995) & 0.10 & 0.34 \\
\hline Arabian Sea & & 2363 & 1.387 & Honjo et al. (1999) & & \\
\hline Arabian Sea & & 3915 & 1.2045 & Honjo et al. (1999) & 0.42 & 0.99 \\
\hline Arabian Sea & $94-95$ & 858 & 6.3875 & Honjo et al. (1999) & & \\
\hline Arabian Sea & & 1857 & 5.9495 & Honjo et al. (1999) & 2.98 & 5.13 \\
\hline Arabian Sea & & 2871 & 4.672 & Honjo et al. (1999) & 2.74 & 4.76 \\
\hline Bay of Benegal & $87-88$ & 1040 & 2.36885 & Ittekkot et al. (1991) & & \\
\hline Bay of Benegal & & 3006 & 2.04035 & Ittekkot et al. (1991) & 0.53 & 1.54 \\
\hline \multicolumn{7}{|l|}{ Polar Antarctic } \\
\hline ACC, Atlantic & 92 & 2453 & 2.4163 & Pudsey and King (1997) & & \\
\hline ACC, Atlantic & & 3259 & 1.02565 & Pudsey and King (1997) & 1.31 & 2.02 \\
\hline ACC, Atlantic & 92 & 2966 & 2.38345 & Pudsey and King (1997) & & \\
\hline ACC, Atlantic & & 3766 & 0.5548 & Pudsey and King (1997) & 1.29 & 2.00 \\
\hline SAE Pacific & $96-98$ & 982 & 1.7009 & Honjo et al. (2000) & & \\
\hline SAE Pacific & & 4224 & 0.62415 & Honjo et al. (2000) (JGOFS) & 0.14 & 0.84 \\
\hline
\end{tabular}

$T_{\mathrm{L}}=T_{\mathrm{U}}-\left(1-e^{-L \cdot \Delta z}\right) \cdot T_{\mathrm{U}}$,

where $L$ is the fractional remineralisation per metre settled. $L$ was calculated from the average carbon-specific respiration rate for the 4 and $15^{\circ} \mathrm{C}$ treatments (Table 1) divided by an average sinking velocity of $150 \mathrm{~m} \mathrm{~d}^{-1}$ for both treatments (Berelson, 2002; Fischer and Karakas, 2009). L was $2.20 \times 10^{-4}$ and $7.64 \times 10^{-4} \mathrm{~m}^{-1}$ for the $4^{\circ} \mathrm{C}$ and $15^{\circ} \mathrm{C}$ treatment, respectively.

$T_{\mathrm{L}}$ calculated using the $4{ }^{\circ} \mathrm{C}$ carbon-specific respiration fitted surprisingly well to the trap-collected $T_{\mathrm{L}}$, while the 3.5 fold higher carbon-specific respiration rate at $15^{\circ} \mathrm{C}$ underestimated the trap-collected $T_{\mathrm{L}}$ (Fig. 5). This indicates that relatively good estimates of deep ocean fluxes can be obtained by inclusions of temperature limitations on respiratory activity alone. Knowledge of particle size spectra at depths would provide better calculations of $T_{\mathrm{L}}$ since it would allow sizespecific sinking speeds instead of average sinking speed for all POC to calculate $L$. Further, temperature deviations from $4{ }^{\circ} \mathrm{C}$ would influence the microbial activity and, thus, the microbial degradation rates. However, the relatively good predictability of these simple estimates indicates that temperature plays a major role for deep ocean fluxes of POC, possibly caused by embedding of temperature-sensitive microbes from the surface ocean within the aggregates at depths.

Acknowledgements. We thank Christiane Lorenzen for assistance during POC measurements. The oxygen microsensors were constructed by Gaby Eickert, Ines Schröder, and Karin Hohmann, Max Planck Institute for Marine Microbiology, Bremen. We thank George Jackson, Gerhard Fischer, and Uta Passow for discussions that improved the manuscript. This study was supported by the Helmholtz Association (to HP), the Alfred Wegener Institute for Polar and Marine Research (to MHI and HP), by the DFG-Research Center/Cluster of Excellence "The Ocean in the Earth System" (to MHI and HP), and the Swedish Research Council (VR, Dnr: 621-2011-4406 to HP).

Edited by: K. Suzuki

\section{References}

Alldredge, A. and Gotschalk, C.: In situ settling behavior of marine snow, Limnol. Oceanogr., 33, 339-351, 1988.

Alldredge, A. L. and Silver, M. W.: Characteristics, dynamics and significance of marine snow, Prog. Oceanogr., 20, 41-82, 1988.

Aristegui, J., Gasol, J. M., Duarte, C. M., and Herndl, G. J.: Microbial oceanography of the dark ocean's pelagic realm, Limnol. Oceanogr., 54, 1501-1529, 2009.

Asper, V. L.: Measuring the flux and sinking speed of marine snow aggregates., Deep-Sea Res., 34, 1-17, 1987.

Asper, V. L. and Smith Jr., W. O.: Abundance, distribution and sinking rates of aggregates in the Ross Sea, Antarctica, Deep-Sea Res. Pt. I, 50, 131-150, 2003.

Berelson, W. M.: Particle settling rates increase with depth on the ocean, Deep-Sea Res. Pt. II, 49, 237-251, 2002.

Bodungen, B. V., Antia, A., Bauerfeind, E., Haupt, O., Koeve, W., Machado, E., Peeken, I., Peinert, R., Reitmeier, S., Thomsen, C., Voss, M., Wunsch, M., Zeller, U., and Zeitzschel, B.: Pelagic processes and vertical flux of particles: an overview of a longterm comparative study in the Norwegian Sea and Greenland Sea, Geol. Rundsch., 84, 11-27, 1995.

Broecker, W. S. and Peng, T. H.: Gas exchange rates between air and sea, Tellus, 26, 21-35, 1974. 
Brzezinski, M. A. and Nelson, D. M.: The annual silica cycle in the Sargasso Sea near Bermuda, Deep-Sea Res. Pt. I, 42, 1215-1237, 1995.

Conte, M. H., Deuser, W. G., Ralf, N., and Ross, E. H.: Seasonal and interannual variability in deep ocean particle fluxes at the Oceanic Flux Program (OFP), Bermuda Atlantic Time-Series (BAT) site in the Western Sargasso Sea near Bermuda, Deep-Sea Res. II, 48, 1471-1505, 2001.

Delong, E. F., Preston, C. M., Mincer, T., Rich, V., Hallam, S. J., Frigaard, N.-U., Martinez, A., Sullivan, M. B., Edwards, R., Brito, B. R., Chrisholm, S. W., and Karl, D. M.: Community Genomics Among Stratified Microbial Assemblages in the Ocean's Interior, Science, 311, 496-503, 2006.

Deuser, W. G., Jickells, T. D., King, P., and Commeau, J. A.: Decadal and annual changes in biogenic opal and carbonate fluxes to the deep Sargasso Sea, Deep-Sea Res. I, 42, 1923-1932, 1995.

Diercks, A. R. and Asper, V. L.: In situ settling speeds of marine snow aggregates below the mixed layer: Black Sea and Gulf of Mexico, Deep-Sea Res Pt. I, 44, 385-398, 1997.

Dymond, J. and Collier, R.: Biogenic particle fluxes in the equatorial Pacific: Evidence for both high and low productivity during 1982-1983 El Nino, Global Biogeochem. Cy., 2, 129-137, 1988.

Eloe, E. A., Shulse, C. N., Fadrosh, D. W., Williamson, S. J., Allen, E. E., and Bartlett, D. H.: Compositional differences in particleassociated and free-living microbial assemblages from an extreme deep-ocean environment, Environ. Microb. Rep., 3, 449458, 2011

Feinberg, L. R. and Dam, H. G.: Effects of diet on dimensions, density and sinking rates of fecal pellets of the copepod Acartia tonsa, Mar. Ecol. Prog. Ser., 175, 87-96, 1998.

Fischer, G. and Wefer, G.: Long-term observation of particle fluxes in the eastern Atlantic: Seasonality, changes of flux with depth and comparison with the sediment record, South Atlantic Present and Past Circulation, 325-344, 1996.

Fischer, G. and Karakas,, G.: Sinking rates and ballast composition of particles in the Atlantic Ocean: implications for the organic carbon fluxes to the deep ocean, Biogeosciences, 6, 85102, doi:10.5194/bg-6-85-2009, 2009.

Fowler, S. W. and Knauer, G. A.: The role of large particles in the transport of elements and organic compounds through the oceanic water column, Prog. Oceanogr., 16, 147-194, 1986.

Grossart, H. and Gust, G.: Hydrostatic pressure affects physiology and community structure of marine bacteria during settling to 4000 m: an experimental approach, Mar. Ecol. Prog. Ser, 390, 97-104, 2009.

Grossart, H. P. and Ploug, H.: Microbial degradation of organic carbon and nitrogen on diatom aggregates, Limnol. Oceanogr., 46, 267-277, 2001.

Guillard, R. L.: Culture of phytoplankton for feeding marine invertebrates, in: Culture of marine invertebrate animals, edited by: Smith, W., L., and Chanley, M., H., Plenum Press, New York, London, 29-60, 1975.

Hedges, J. I.: Global biogeochemical cycles: Progress and problems, Mar. Chem., 39, 67-93, 1992.

Honjo, S.: Material fluxes and modes of sedimentation in the mesopelagic and bathypelagic zones, J. Mar. Res., 38, 53-97, 1980.
Honjo, S.: Data presented in Honjo et al. 2008, Prog. Oceanogr., 76, 217-285, 1992.

Honjo, S.: Data presented in Honjo et al. 2008, Prog. Oceanogr., 76, 217-285, 1993.

Honjo, S. and Manganini, S. J.: Annual biogenic particle fluxes to the interior of the North Atlantic Ocean; studied at $34^{\circ} \mathrm{N} 21^{\circ} \mathrm{W}$ and $48^{\circ} \mathrm{N} 21^{\circ} \mathrm{W}$, edited by: Ducklow, H. W. and Harris, R. P., 1993.

Honjo, S., Francois, R., Manganini, S., Dymond, J., and Collier, R.: Particle fluxes to the interior of the Southern Ocean in the Western Pacific sector along $170^{\circ} \mathrm{W}$, Deep-Sea Res. II, 47, 35213548, 2000.

Honjo, S., Manganini, S. J., Krishfield, R. A., and Francois, R.: Particulate organic carbon fluxes to the ocean interior and factors controlling the biological pump: A synthesis of global sediment trap programs since 1983, Prog. Oceanogr., 76, 217-285, 2008.

Hoppe, H. G., Breithaupt, P., Walther, K., Koppe, R., Bleck, S., Sommer, U., and Jürgens, K.: Climate warming in winter affect the coupling between phytoplankton and bacteria during the spring bloom: a mesocosm study, Aquat. Microb. Ecol., 51, 105115, 2008.

Ittekkot, V., Nair, R., Honjo, S., Ramaswamy, V., Bartsch, M., Manganini, S. J., and Desai, B. N.: Enhanced particle flux in Bay of Bengal induced by injection of water, Nature, 351, 385-387, 1991.

Iversen, M. H. and Ploug, H.: Ballast minerals and the sinking carbon flux in the ocean: carbon-specific respiration rates and sinking velocity of marine snow aggregates, Biogeosciences, 7 , 2613-2624, doi:10.5194/bg-7-2613-2010, 2010.

Iversen, M. H., Nowald, N., Ploug, H., Jackson, G. A., and Fischer, G.: High resolution profiles of vertical particulate organic matter export off Cape Blanc, Mauritania: Degradation processes and ballasting effects, Deep-Sea Res. Pt. I, 57, 771-784, doi:10.1016/j.dsr.2010.03.007, 2010.

Jianfang, C., Lianfu, Y., Weisner, M. G., Ronghua, C., Yulong, Z., and Wong, K. H.: Estimations of primary productivity and export production in the South China Sea based on sediment trap experiments, Chin. Sci. Bull., 43, 585-586, 1998.

Kempe, S., and Knaack, H.: Vertical particle flux in the western Pacific below the north equatorial current and the equatorial counter current, in: Particle flux in the Ocean, edited by: Ittekkot, V., Schäfer, P., Honjo, S., and Depetris, P. J., John Wiley and Sons, West Sussex, 313-323, 1996.

Kepkay, P. E.: Particle aggregation and the biological reactivity of colloids, Mar. Ecol. Prog. Ser, 109, 293-304, 1994.

Kiørboe, T., Ploug, H., and Thygesen, U. H.: Fluid motion and solute distribution around sinking aggregates. I. Small-scale fluxes and heterogeneity of nutrients in the pelagic environment, Mar. Ecol. Prog. Ser., 211, 1-13, 2001.

Kiørboe, T., Grossart, H. P., Ploug, H., and Tang, K.: Mechanisms and Rates of Bacterial Colonization of Sinking Aggregates, Appl. Environ. Microbiol., 68, 3996-4006, 2002.

Kumar, M. D., Sarma, V. V. S. S., Ramaiah, N., Gauns, M., and de Sousa, S. N.: Biogeochemical significance of transport exopolymer particles in the Indian Ocean, Geophys. Res. Lett., 25, 81-84, 1998.

Kuss, J. and Kremling, K.: Particulate trace element fluxes in the deep northeast Atlantic Ocean, Deep-Sea Res., 46, 149-169, 1999. 
Lutz, M., Dunbar, R., and Caldeira, K.: Regional variability in the vertical flux of particulate organic carbon in the ocean interior, Global Biogeochem. Cy., 16, 1-18, doi:10.1029/2000GB001383, 2002.

Maas, L. R. M.: On the surface area of an ellipsoid and related integrals of elliptic integrals, J. Comp. Appl. Math., 51, 237-249, 1994.

Martin, J. H., Knauer, G. A., Karl, D. M., and Broenkow, W. W.: VERTEX: carbon cycling in the northeast Pacific, Deep-Sea Res., 34, 267-285, 1987.

Moeseneder, M. M., Winter, C., and Herndl, G. J.: Horizontal and vertical complexity of attached and free-living bacteria of the eastern Mediterranean Sea, determined by $16 \mathrm{~S}$ rDNA and $16 \mathrm{~S}$ rRNA fingerprints, Limnol. Oceanogr., 46, 95-107, 2001.

Moriceau, B., Goutx, M., Guigue, C., Lee, C., Armstrong, R. A., Duflos, M., Tamburini, C., Charrière, B., and Ragueneau, O.: $\mathrm{Si}-\mathrm{C}$ interactions during degradation of the diatom Skeletonema marinoi, Deep-Sea Res. Pt. II, 56, 1381-1395, 2009.

Nagata, T., Tamburini, C., Arístegui, J., Baltar, F., Bochdansky, A. B., Fonda-Umani, S., Fukuda, H., Gogou, A., Hansell, D. A., Hansman, R. L., Herndl, G. J., Panagiotopoulos, C., Reinthaler, T., Sohrin, R., Verdugo, P., Yamada, N., Yamashita, Y., Yokokawa, T., and Bartlett, D. H.: Emerging concepts on microbial processes in the bathypelagic ocean - ecology, biogeochemistry, and genomics, Deep-Sea Res. Pt. II, 57, 1519-1536, doi:10.1016/j.dsr2.2010.02.019, 2010.

Passow, U. and Alldredge, A.: A dye-binding assay for the spectrophotometric measurement of transparent exopolymer particles (TEP), Limnol. Oceanogr., 40, 1326-1335, 1995.

Passow, U., Shipe, R. F., Murray, A., Pak, D. K., Brzezinski, M. A., and Alldredge, A. L.: The origin of transparent exopolymer particles (TEP) and their role in the sedimentation of particulate matter, Cont. Shelf Res., 21, 327-346, 2001.

Piontek, J., Händel, N., Langer, G., Wohlers, J., Riebesell, U., and Engel, A.: Effects of rising temperature on the formation and microbial degradation of marine diatom aggregates, Aquat. Microb. Ecol., 54, 305-318, 2009.

Ploug, H.: Small-scale oxygen fluxes and remineralization in sinking aggregates, Limnol. Oceanogr., 46, 1624-1631, 2001.

Ploug, H. and Grossart, H. P.: Bacterial growth and grazing on diatom aggregates: Respiratory carbon turnover as a function of aggregate size and sinking velocity, Limnol. Oceanogr., 45, 1467$1475,2000$.

Ploug, H. and Jørgensen, B. B.: A net-jet flow system for mass transfer and microsensor studies of sinking aggregates, Mar. Ecol. Prog. Ser., 176, 279-290, 1999.

Ploug, H., Kuehl, M., Buchholz-Cleven, B., and Jørgensen, B. B.: Anoxic aggregates - An ephemeral phenomenon in the pelagic environment?, Aquat. Microb. Ecol., 13, 285-294, 1997.

Ploug, H., Grossart, H. P., Azam, F., and Jørgensen, B. B.: Photosynthesis, respiration, and carbon turnover in sinking marine snow from surface waters of Southern California Bight: Implications for the carbon cycle in the ocean, Mar. Ecol. Prog. Ser., 179, 1-11, 1999.

Ploug, H., Iversen, M. H., and Fischer, G.: Ballast, sinking velocity, and apparent diffusivity within marine snow and zooplankton fecal pellets: Implications for substrate turnover by attached bacteria, Limnol. Oceanogr., 53, 1878-1886, 2008.
Ploug, H., Terbrüggen, A., Kaufmann, A., Wolf-Gladrow, D., and Passow, U.: A novel method to measure particle sinking velocity in vitro, and its comparison to three other in vitro methods, Limnol. Oceanogr.-Methods, 8, 386-393, 2010.

Pudsey, C. J. and King, P.: Particle fluxes, benthic processes and the palaeoenvironmental record in the northern Weddell Sea, DeepSea Res. I, 44, 1841-1876, 1997.

Revsbech, N. P.: An oxygen microsensor with a guard cathode, Limnol. Oceanogr., 34, 474-478, 1989.

Sarno, D., Kooistra, W. H. C. F., Medlin, L. K., Percopo, I., and Zingone, A.: Diversity in the genus Skeletonema (Bacillariophyceae): II An assessment of the taxonomy of S. costatum-like species with the description of four new species, J. Phycol., 41, 151-176, 2005.

Scholten, J. C., Fietzke, J., Vogler, S., Loeff, M. M. R., Mangini, A., Koeve, W., Waniek, J., Stoffers, P., Antia, A., and Kuss, J.: Trapping efficiencies of sediment traps from the deep eastern North Atlantic: the 230Th calibration, Deep-Sea Res. II, 48, 2383-2408, 2001.

Schwinghamer, P.: Seperation and concentration of living dinoflagellate resting cysts from marine sediments via density-gradient centrifugation, Limnol. Oceanogr, 36, 588-592, 1991.

Stemmann, L., Jackson, G. A., and Gorsky, G.: A vertical model of particle size distributions and fluxes in the midwater column that includes biological and physical processes; Part II, Application to a three year survey in the NW Mediterranean Sea, Deep-Sea Res. Pt. I, 51, 885-908, 2004.

Stokes, G. G.: On the effect of the internal friction of fluids on the motion of pendulums, Transaction of the Cambridge Philosophical Society, 9, 8-106, 1851.

Suess, E.: Particulate organic carbon flux in the oceans - surface productivity and oxygen utilization, Nature, 288, 260-263, 1980.

Tamburini, C., Garcin, J., and Bianchi, A.: Role of deep-sea bacteria in organic matter mineralization and adaptation to hydrostatic pressure conditions in the NW Mediterranean Sea, Aquat. Microb. Ecol., 32, 209-218, 2003.

Tamburini, C., Garcin, J., Gregori, G., Leblanc, K., Rimmelin, P., and Kirchman, D. L.: Pressure effects on surface Mediterranean prokaryotes and biogenic silica dissolution during a diatom sinking experiment, Aquat. Microb. Ecol., 43, 267-276, 2006.

Tamburini, C., Goutx, M., Guigue, C., Garel, M., Lefevre, D., Charrière, B., Sempere, R., Pepa, S., Peterson, M., Wakeham, S. G., and Lee, C.: Effects of hydrostatic pressure on microbial alteration of sinking fecal pellets, Deep-Sea Res. Pt. II, 56, 15331546, 2009.

Usbeck, R.: Modeling of marine biogeochemical cycles with an emphasis on vertical particle fluxes, Rep. Polar Res., 332, 105 pp., 1999.

Verity, P. G., Williams, S. C., and Hong, Y.: Formation, degradation, and mass:volume ratios of detritus derived from decaying phytoplankton, Mar. Ecol. Prog. Ser., 207, 53-68, 2000.

Volk, T. and Hoffert, M. I.: Ocean carbon pumps: analysis of relative strengths and efficiencies in ocean-driven atmospheric $\mathrm{CO}_{2}$ changes, in: The Carbon Cycle and Atmospheric $\mathrm{CO}_{2}$ : Natural Variations Archean to Present, edited by: Sundquist, E. T. and Broecker, W. S., AGU, Washington DC, 99-110, 1985.

Wefer, G. and Fischer, G.: Seasonal patterns of vertical particle flux in equatorial and coastal upwelling areas of the eastern Atlantic, Deep-Sea Res. I, 40, 1613-1645, 1993. 
White, F. M.: Viscous fluid flow, 2nd Edn., McGraw-Hill ed., Inc. New York, New York, 1974.

White, P. A., Kalff, J., Rasmussen, J. B., and Gasol, J. M.: The Effect of Temperature and Algal Biomass on Bacterial Production and Specific Growth Rate in Freshwater and Marine Habitats, Microb. Ecol., 21, 99-118, 1991.
Wong, C. S., Whitney, F. A., Crawford, D. W., Iseki, K., Matear, R. J., Johnson, W. K., Page, J. S., and Timothy, D.: Seasonal and interannual variability in particle fluxes of carbon, nitrogen and silicon from time series of sediment traps at Ocean Station P, 1982-1993: Relationship to changes in subarctic primary production, Deep-Sea Res. II, 46, 2735-2760, 1999. 